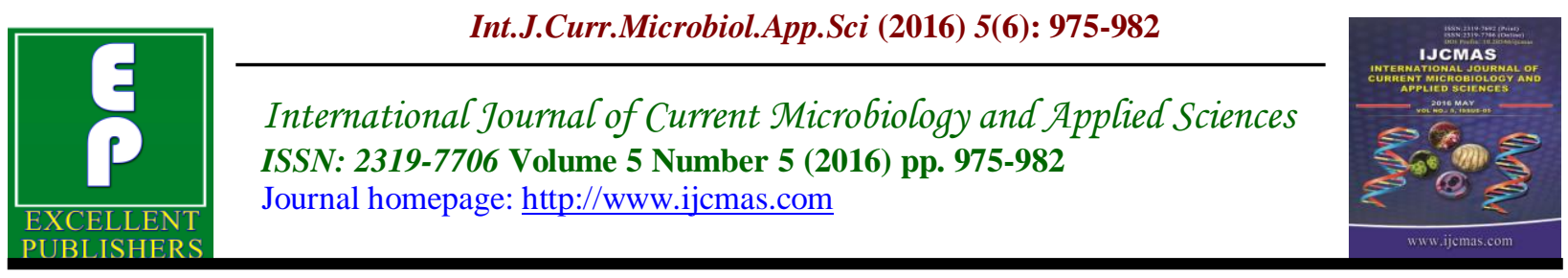

Original Research Article

http://dx.doi.org/10.20546/ijcmas.2016.505.103

\title{
Studies on the Toxicity of Chromium (VI) to Pistia stratiotes L. Plant and its Removal
}

\author{
Piyush Kanti Dan ${ }^{1}$, Sunandana Mandal ${ }^{2}$, Anil Kr. De ${ }^{2}$ and Sudhendu Mandal ${ }^{1 *}$ \\ ${ }^{1}$ Department of Botany, Visva-Bharati University, Santiniketan- 731235, India \\ ${ }^{2}$ Department of Chemistry, Visva-Bharati University, Santiniketan- 731235, India \\ *Corresponding author
}

\begin{tabular}{ll}
\hline & A B S T R A C T \\
\cline { 2 - 3 } $\begin{array}{l}\text { Keywords } \\
\text { Toxic effect, } \\
\text { Chromium (VI), } \\
\begin{array}{l}\text { Pistia plant, } \\
\text { Removal from } \\
\text { waste water. }\end{array}\end{array}$ \\
$\begin{array}{l}\text { Rapid growth of industrialization leads to pollution due to waste water. Many } \\
\text { countries have experienced pollution hazards due to toxic metals. Industrial waste } \\
\text { effluents containing toxic metals are creating water pollution problems. The present } \\
\text { paper reports on the systematic studies of the uptake of Cr (VI) and the effect of the } \\
\text { metal on some biochemical constituents of the plant Pistia stratiotes L. The } \\
\text { biochemical parameters were : Hill activity, Chlorophylls, protein, free amino acid, } \\
\text { inorganic phosphorus, RNA, DNA, dry weight and the activities of Protease, }\end{array}$ \\
$\begin{array}{l}\text { RNase and Peroxidase, etc. The effects on the biochemical parameters differed } \\
\text { from those in control experiments. The absorption of the metal by the plants }\end{array}$ \\
$\begin{array}{l}\text { Accepted: } \\
\text { gradually increased with increase in concentration of Cr (VI) in the culture } \\
\text { Available Online: } \\
\text { 10 May 2016 }\end{array}$ & $\begin{array}{l}\text { medium. The aquatic plant species may be regarded as Cr (VI) accumulators. So, } \\
\text { the plant Pistia stratiotes L. can serve the mankind as the scavenger of Cr (VI) } \\
\text { from waste water. }\end{array}$ \\
\hline
\end{tabular}

\section{Introduction}

Water pollution by toxic chemicals present in industrial waste effluents is a worldwide problem now. Both developed and developing countries are seriously affected due to this water pollution. Many industries like chrome plating, leather, fertilizer, etc. discharge waste effluent containing $\mathrm{Cr}$ (VI) into surface waters.

The permissible limit of $\mathrm{Cr}(\mathrm{VI})$ in drinking water is $0.05 \mathrm{mg} / \mathrm{l}$. It is irritating to mucous membranes. It causes ulcerations and a variety of respiratory, gastrointestinal, lung and skin complications (Sterrett, 1978). Attempts were made in our laboratory to develop methods for the removal of $\mathrm{Cr}$ (VI) (Sen et al., 1979, 1980) from aqueous solutions using hydrous oxides of Sn (IV) and $\mathrm{Zr}$ (IV). Aquatic plant Pistia has been used in our laboratory for the removal of $\mathrm{Hg}$ (II) (De, et al., 1985). Eichhornia, Oedogonium and Hydrilla were also used for the removal of $\mathrm{Hg}$ (II) and $\mathrm{Cr}$ (VI). The results of all these studies have_encouraged us to undertake investigation for the removal of $\mathrm{Cr}$ (VI) by Pistia. This paper reports the results of the uptake of $\mathrm{Cr}$ (VI) by Pistia plant and effect of the metal on the changes in some biochemical processes. 


\section{Materials and Methods}

\section{Plant material}

The young plants, Pistia stratiotes L., were collected from uncontaminated fresh water pond around Visva-Bharati University campus, Santiniketan, West Bengal, India. The collected plants were grown in a greenhouse at $30 \pm 2^{\circ} \mathrm{C}$. Generally 5 to 10 days were required for the maturity of the plant. Only mature plants were used during this investigation.

\section{Treatment with $\mathrm{Cr}(\mathrm{VI})$}

Six plastic tumblers $(20 \mathrm{~L})$ were filled with $10 \mathrm{~L}$ of culture medium each. The culture medium of $\mathrm{pH} 7.5$ was prepared as per Hewitt (1963) with slight modification necessary for adjustment of lower concentration of nutrients required for aquatic plants. From a stock solution of $\mathrm{Na} 2 \mathrm{CrO} 4$ different volumes of solution were added to the culture medium separately in order to maintain different concentrations of Cr (VI) (0.5 ppm to $10.0 \mathrm{ppm})$. In order to check the loss of $\mathrm{Cr}$ (VI) from experimental systems due to evaporation and adsorption on the walls of the containers a control experiment without plant was performed simultaneously with the experimental run.

Plastia plants (200 g) were floated in each tumbler. They were cultured in a natural environmental condition in a greenhouse during summer season.

Analysis of uptake of $\mathrm{Cr}$ (VI) was made in both culture medium and plants after 1, 2, 3, 4, 5, 6 and 7 days of contact. Biochemical parameters like chlorophyll, protein, free amino acid, DNA, RNA, Hill activity, dry weight and drift of activities of enzymes like protease, catalase, peroxidase and acid and alkaline pyrophosphatases were analysed in the treated plants.

\section{Biochemical Parameters}

Total chlorophyll, chlorophyll (a) and chlorophyll (b) were estimated by the method of Knudson et al., (1977). For protein estimation, phenolic compounds were removed by the method of Kar and Mishra (1976); protein was then extracted from the residue after removal of chlorophyll by digesting with $0.5 \mathrm{~N} \mathrm{NaOH}$ at $80^{\circ} \mathrm{C}$ for $1 \mathrm{hr}$ and estimated by Folinphenol reagent (Lowry et al., 1951). Free amino acid was extracted according to Dwivedi, et al., (1979) and estimated spectrophotometrically by the method of Moore and Stein (1948). DNA and RNA were extracted (Cherry, 1962) and RNA was estimated by the method of Markham (1955) and DNA by the method of Burton (1956) as modified by Choudhuri and Chatterjee (1970). The Hill Activity was measured by the method of Kaniuga et al., (1978) following the modification by Jana and Choudhuri (1982). Dry weight of the samples was determined by drying the weighed samples at $80^{\circ} \mathrm{C}$ in a hot air oven for four days and reweighing. Hill activity was expressed as $\mu$ mole dichlorophenolindophenol (DCIP) reduced /mg chlorophyll $/ \mathrm{hr}$.

For enzyme assays, the protease, catalase and peroxidase were extracted (Kar and Mishra, 1976) in phosphate buffer ( $\mathrm{pH}$ 6.5). The protease activity was estimated by the method of Snell and Snell (1971) with little modification (Biswas and Choudhuri, 1978). Residual protein was measured by Folin- phenol reagent (Lowry et al., 1951). Catalase activity was measured by the method of Biswas and Choudhuri, (1978) while peroxidase activity by the method of Kar and Mishra (1976) using pyrogallol as co-substrate. Extraction and measurement of the activities of acid and alkaline pyrophosphatases were done 
according to the methods of Kar and Mishra (1975).

For all enzyme assays, zero time control was taken as a blank and the activities of enzymes except protease were expressed as

$$
\left(\begin{array}{ccc}
\Delta A & X \\
\hline T V & T & X \\
v & &
\end{array}\right)
$$

where $\Delta \mathrm{A}$ is the absorbance of the sample after incubation minus the absorbance at zero time control; $\mathrm{TV}$ is the total volume of the filtrate, (t) is the time (hr) of incubation with substrate and (v) is the volume of filtrate taken for incubation (Fick and Qualsett, 1975). Protease activity was expressed as $\mu \mathrm{g}$ of protein hydrolysed $/ \mathrm{hr} / \mathrm{g}$ fresh weight.

Each experiment was carried out ten times and the mean values with standard deviation are given in the tables.

\section{Results and Discussion}

\section{Uptake of Cr(VI) by Pistia}

Pistia plants, water and sediment samples collected from the selected pond were analyzed for $\mathrm{Cr}$ (VI) and it was observed that they were free from detectable $\mathrm{Cr}$ (VI) contamination.

At $20 \mathrm{ppm}$ of $\mathrm{Cr}$ (VI), the plants died after 3 days but at $0.5,1.0,5.0$ and $10.0 \mathrm{ppm}$ the study was undertaken upto 7 days and it is evident from the results that the plants were affected to a greater extent in case of 5.0 and $10.0 \mathrm{ppm}$ concentration of $\mathrm{Cr}$ (VI). The day by day removal of $\mathrm{Cr}(\mathrm{VI})$ from the culture medium is represented, while the results of 3 and 5 days of contact are tabulated in Table I. The results of 6 and 7 days of contact did not show any significant change. It is evident that the plants took up maximum $\mathrm{Cr}$ (VI) and accumulated it mainly in roots within 5 days. The $\mathrm{Cr}(\mathrm{VI})$ content in shoots is negligible upto 3 days and then increased slightly with the time of exposure. Actually, 90 to $95 \%$ of $\mathrm{Cr}$ (VI) was accumulated in the roots in each case. When the tumbler contained 5.0 and $10.0 \mathrm{mg}$ per $10 \mathrm{~L}$ the $\mathrm{Cr}$ (VI) was totally absorbed by the plants. Percent removal of $\mathrm{Cr}$ (VI) gradually decreased with increasing concentrations. At lower concentrations, however, the accumulation of $\mathrm{Cr}$ (VI) occurred mainly in roots. The possible explanation is that probably $\mathrm{Cr}$ (III) is formed due to reduction and forms complexes with $\mathrm{COOH}$ groups (Sigel, 1973) in the roots thus preventing it from passing into the shoot system.

\section{Toxic Effects of $\mathrm{Cr}$ (VI) on Changes in some Biochemical Parameters of Pistia}

From Table II, it is evident that at $10 \mathrm{ppm}$ of Cr (VI), Chlorophyll a and b decreased with the time of exposure. At 0.5 and 1.0 ppm concentrations there was no significant change in these parameters over control with time. The results suggest that at 10 ppm the Cr (VI) lowered the chlorophyll by decreasing the synthesis of chlorophyll as possibly by increasing chlorophyllase activity. The lower ration of chlorophyll a to $b$ was obtained due to a greater decline in chlorophyll a compared to chlorophyll $b$. It also suggests that activities of both the photosystems (PI and PII) may be equally active and C3 type of metabolism was prevalent in this species (Black and Mayne, 1970). Fig. 2 shows that $\mathrm{Cr}$ (VI) affected least Hill activity at 0.5 and 1.0 ppm concentration. However, Hill activity declined with increasing contact time in days at $>5 \mathrm{ppm}$ of $\mathrm{Cr}$ (VI). Our results reveal the disorder of chloroplast membrane and inactivation of electron transport of photosystem II (Shioi et al., 1978) at $>5$ ppm of $\mathrm{Cr}$ (VI). 
Tables III and IV show the effect of Cr (VI) on changes in protein, free amino acid, DNA and RNA after 3 and 5 days of contact. Protein content decreased in the shoot system with the treatment of $\mathrm{Cr}$ (VI) at 10 ppm, while in root system the value remained more or less same as the control. Below $5 \mathrm{ppm}$, the protein content showed no significant change over control. In all the treatments, free amino acid decreased in roots with increasing concentration of $\mathrm{Cr}$ (VI), while in shoots it increased with concentration. So Cr (VI) exerted its adverse influence more in roots than in shoots. DNA content remained the same as that in control in roots and shoots. At $10 \mathrm{ppm}$ the RNA content decreased of control roots and shoots. At bellow $5 \mathrm{ppm}$ the values were more or less the same as that in control. A decrease in RNA content with time at 10 ppm was due to the fact that $\mathrm{Cr}$ (III), produced due to reduction of $\mathrm{Cr}(\mathrm{VI})$, was tied with DNA and RNA molecules and changed the conformation of nucleic acids. It can be stated here that the binding of $\mathrm{Cr}$ (III) with RNA prevents its degradation by RNase. At $10 \mathrm{ppm}$, the dry weight increased in both roots and shoots; while below $1 \mathrm{ppm}$ the value remained the same as that in control (Table V).

Table.1 Absorption of Cr(VI) by Pistia Plants after 3 and 5 Days of Contact*

\begin{tabular}{|c|c|c|c|c|c|c|c|c|}
\hline \multirow{4}{*}{$\begin{array}{l}\text { Initial } \\
\text { absorption by plants } \\
\text { Amount of } \\
\text { Cr(VI) } \\
\text { (mg/101) }\end{array}$} & \multirow{3}{*}{\multicolumn{2}{|c|}{$\begin{array}{c}\mathrm{Cr}(\mathrm{VI}) \text { in culture } \\
\text { medium after } \\
(\mathrm{mg} / 101)\end{array}$}} & \multicolumn{6}{|c|}{$\mathrm{Cr}(\mathrm{VI})$ Absorbed by Plants } \\
\hline & & & \multicolumn{2}{|c|}{ Root } & \multicolumn{3}{|c|}{ Shoot } & Whole plant \\
\hline & & & \multicolumn{2}{|c|}{$(\mathrm{mg} / \mathrm{g}$ fresh $\mathrm{wt})$} & \multicolumn{3}{|c|}{$(\mathrm{mg} / \mathrm{g}$ fresh $\mathrm{wt})$} & $(\mathrm{mg} / \mathrm{g}$ fresh $\mathrm{wt})$ \\
\hline & 3 & 5 & 3 & 5 & 3 & 5 & 3 & 5 \\
\hline 5 & 1.03 & 0.00 & 0.05 & 0.06 & trace & 0.001 & 0.017 & 0.021 \\
\hline 10 & \pm 0.02 & $\begin{array}{l} \pm 0.00 \\
1.54\end{array}$ & $\begin{array}{c} \pm 0.003 \\
0.08\end{array}$ & $\begin{array}{c} \pm 0.001 \\
0.106\end{array}$ & & \pm 0.001 & \pm 0.001 & \pm 0.001 \\
\hline 10 & $\begin{array}{r}3.53 \\
\pm 0.05\end{array}$ & $\begin{array}{l}1.04 \\
\pm 0.01\end{array}$ & $\begin{array}{r}0.00 \\
\pm 0.007\end{array}$ & $\begin{array}{r}0.100 \\
\pm 0.009\end{array}$ & +0.0001 & $\begin{array}{r}0.0017 \\
+0.0001\end{array}$ & $\begin{array}{r}0.027 \\
+0.002\end{array}$ & $\begin{array}{r}0.037 \\
+0.003\end{array}$ \\
\hline 50 & 40.65 & 33.75 & 0.116 & 0.203 & 0.004 & 0.007 & 0.041 & 0.073 \\
\hline & \pm 0.4 & \pm 0.5 & \pm 0.001 & \pm 0.003 & \pm 0.001 & \pm 0.0008 & \pm 0.0007 & \pm 0.003 \\
\hline 100 & $\begin{array}{r}88.1 \\
+00\end{array}$ & 78.2 & 0.14 & 0.173 & 0.0072 & 0.012 & 0.052 & 0.100 \\
\hline & \pm 0.9 & \pm 0.8 & \pm 0.004 & \pm 0.005 & \pm 0.0002 & \pm 0.0009 & \pm 0.005 & \pm 0.007 \\
\hline
\end{tabular}

*Each value is the mean of ten replicates \pm S.D.

Table.2 Effect of Toxicity of Cr VI) on Chlorophyll Content (mg/g Fresh wt) in the Leaves of Pistia after Different durations of Contact

\begin{tabular}{|c|c|c|c|c|c|c|c|c|c|}
\hline \multirow{4}{*}{$\begin{array}{l}\text { Treatment } \\
\text { (ppm }\end{array}$} & \multicolumn{9}{|c|}{ Chlorophyll } \\
\hline & \multicolumn{3}{|c|}{$\mathrm{a}$} & \multicolumn{3}{|c|}{$\mathrm{b}$} & \multicolumn{3}{|c|}{$a: b$} \\
\hline & \multicolumn{9}{|c|}{ Contact Time in Days } \\
\hline & 0 & 3 & 5 & 0 & 3 & 5 & 0 & 3 & 5 \\
\hline \multirow[t]{2}{*}{ Control } & 0.789 & 0.785 & 0.780 & 0.185 & 0.183 & 0.182 & 4.26 & 4.28 & 4.28 \\
\hline & \pm 0.002 & \pm 0.003 & \pm 0.005 & \pm 0.003 & \pm 0.002 & \pm 0.004 & \pm 0.006 & \pm 0.003 & \pm 0.005 \\
\hline \multirow[t]{2}{*}{0.5} & 0.789 & 0.784 & 0.778 & 0.185 & 0.183 & 0.182 & 4.26 & 4.28 & 4.27 \\
\hline & \pm 0.002 & \pm 0.002 & \pm 0.006 & \pm 0.003 & \pm 0.001 & \pm 0.002 & \pm 0.006 & \pm 0.004 & \pm 0.003 \\
\hline \multirow[t]{2}{*}{1.0} & 0.789 & 0.782 & 0.775 & 0.185 & 0.181 & 0.180 & 4.26 & 4.32 & 4.30 \\
\hline & \pm 0.002 & \pm 0.004 & \pm 0.005 & \pm 0.003 & \pm 0.002 & \pm 0.002 & \pm 0.006 & \pm 0.003 & \pm 0.005 \\
\hline \multirow[t]{2}{*}{5.0} & 0.789 & 0.735 & 0.679 & 0.185 & 0.176 & 0.169 & 4.26 & 4.17 & 4.02 \\
\hline & \pm 0.002 & \pm 0.004 & \pm 0.007 & \pm 0.003 & \pm 0.004 & \pm 0.005 & \pm 0.006 & \pm 0.008 & \pm 0.009 \\
\hline \multirow[t]{2}{*}{10.0} & 0.789 & 0.678 & 0.583 & 0.185 & 0.175 & 0.164 & 4.26 & 3.87 & 3.55 \\
\hline & \pm 0.002 & \pm 0.005 & \pm 0.008 & \pm 0.003 & \pm 0.004 & \pm 0.003 & \pm 0.006 & \pm 0.007 & \pm 0.005 \\
\hline
\end{tabular}

* Each value is the mean of ten replicates $\pm \mathrm{S}$. D. 
Table.3 Effect of Toxicity of Cr (VI) on Changes in Protein and Free Amino Acid (mg/g Fresh wt) in Pistia after Different Durations

of Contact*

\begin{tabular}{|c|c|c|c|c|c|c|}
\hline \multirow{3}{*}{$\begin{array}{l}\text { Root, shoot and Cr (VI) } \\
\text { With concerntration (ppm) }\end{array}$} & \multicolumn{3}{|c|}{ Protein } & \multicolumn{3}{|c|}{ Free Amino Acid } \\
\hline & \multicolumn{6}{|c|}{ Contact Time in Days } \\
\hline & 0 & 3 & 5 & 0 & 3 & 5 \\
\hline \multirow[t]{2}{*}{ Root control } & 16.2 & 15.7 & 15.5 & 0.29 & 0.35 & 0.36 \\
\hline & \pm 0.002 & \pm 0.003 & \pm 0.004 & \pm 0.003 & \pm 0.005 & \pm 0.004 \\
\hline \multirow[t]{2}{*}{0.5} & 16.2 & 15.6 & 15.4 & 0.29 & 0.37 & 0.34 \\
\hline & \pm 0.002 & \pm 0.004 & \pm 0.003 & \pm 0.003 & \pm 0.006 & \pm 0.006 \\
\hline \multirow[t]{2}{*}{1.0} & 16.2 & 15.4 & 15.2 & 0.29 & 0.32 & 0.30 \\
\hline & \pm 0.002 & \pm 0.002 & \pm 0.003 & \pm 0.003 & \pm 0.003 & \pm 0.002 \\
\hline \multirow[t]{2}{*}{5.0} & 16.2 & 14.8 & 14.5 & 0.29 & 0.30 & 0.29 \\
\hline & \pm 0.002 & \pm 0.005 & \pm 0.006 & \pm 0.003 & \pm 0.008 & \pm 0.007 \\
\hline \multirow[t]{2}{*}{10.0} & 16.2 & 14.3 & 14.0 & 0.29 & 0.29 & 0.28 \\
\hline & \pm 0.002 & \pm 0.004 & \pm 0.003 & \pm 0.003 & \pm 0.001 & \pm 0.005 \\
\hline \multirow[t]{2}{*}{ Shoot control } & 12.5 & 12.9 & 13.4 & 0.07 & 0.08 & 0.08 \\
\hline & \pm 0.003 & \pm 0.002 & \pm 0.001 & \pm 0.004 & \pm 0.002 & \pm 0.004 \\
\hline \multirow[t]{2}{*}{0.5} & 12.5 & 13.2 & 13.8 & 0.07 & 0.08 & 0.09 \\
\hline & \pm 0.003 & \pm 0.004 & \pm 0.005 & \pm 0.004 & \pm 0.005 & \pm 0.006 \\
\hline \multirow[t]{2}{*}{1.0} & 12.5 & 13.5 & 14.1 & 0.07 & 0.09 & 0.10 \\
\hline & \pm 0.003 & \pm 0.002 & \pm 0.001 & \pm 0.004 & \pm 0.003 & \pm 0.001 \\
\hline \multirow[t]{2}{*}{5.0} & 12.5 & 12.1 & 11.5 & 0.07 & 0.10 & 0.12 \\
\hline & \pm 0.003 & \pm 0.006 & \pm 0.007 & \pm 0.004 & \pm 0.007 & \pm 0.008 \\
\hline \multirow[t]{2}{*}{10.0} & 12.5 & 11.2 & 9.9 & 0.07 & 0.11 & 0.13 \\
\hline & \pm 0.003 & \pm 0.009 & \pm 0.008 & \pm 0.004 & \pm 0.005 & \pm 0.009 \\
\hline
\end{tabular}

$*$ Each value is the mean of ten replicates $\pm S$. D.

Table.4 Effect of Toxicity of Cr (VI) on Changes in DNA and RNA (mg/g Fresh wt) in Pistia after different Durations of Contact*

\begin{tabular}{|c|c|c|c|c|c|c|}
\hline \multirow{3}{*}{$\begin{array}{l}\text { Root, shoot and } \mathrm{Cr} \text { (VI) with } \\
\text { Concentration (ppm }\end{array}$} & \multicolumn{3}{|c|}{ DNA } & \multicolumn{3}{|c|}{ RNA } \\
\hline & \multicolumn{6}{|c|}{ Contact Time in Days } \\
\hline & 0 & 3 & 5 & 0 & 3 & 5 \\
\hline \multirow[t]{2}{*}{ Root control } & 2.7 & 2.7 & 2.8 & 15.8 & 17.9 & 18.4 \\
\hline & \pm 0.02 & \pm 0.04 & \pm 0.01 & \pm 0.04 & \pm 0.06 & \pm 0.08 \\
\hline \multirow[t]{2}{*}{0.5} & 2.7 & 2.7 & 2.6 & 15.8 & 18.0 & 18.7 \\
\hline & \pm 0.02 & \pm 0.05 & \pm 0.04 & \pm 0.04 & \pm 0.03 & \pm 0.05 \\
\hline \multirow[t]{2}{*}{1.0} & 2.7 & 2.7 & 2.6 & 15.8 & 18.2 & 19.3 \\
\hline & \pm 0.02 & \pm 0.02 & \pm 0.01 & \pm 0.04 & \pm 0.03 & \pm 0.01 \\
\hline \multirow[t]{2}{*}{5.0} & 2.7 & 2.7 & 2.6 & 15.8 & 15.3 & 15.1 \\
\hline & \pm 0.02 & \pm 0.05 & \pm 0.05 & \pm 0.04 & \pm 0.09 & \pm 0.09 \\
\hline \multirow[t]{2}{*}{10.0} & 2.7 & 2.6 & 2.6 & 15.8 & 15.0 & 14.7 \\
\hline & \pm 0.02 & \pm 0.03 & \pm 0.04 & \pm 0.04 & \pm 0.07 & \pm 0.06 \\
\hline \multirow[t]{2}{*}{ Shoot control } & 2.6 & 2.7 & 2.7 & 17.7 & 18.5 & 19.6 \\
\hline & \pm 0.03 & \pm 0.02 & \pm 0.05 & \pm 0.05 & \pm 0.03 & \pm 0.04 \\
\hline \multirow[t]{2}{*}{0.5} & 2.6 & 2.6 & 2.6 & 17.7 & 18.6 & 19.8 \\
\hline & \pm 0.03 & \pm 0.05 & \pm 0.04 & \pm 0.05 & \pm 0.06 & \pm 0.05 \\
\hline \multirow[t]{2}{*}{1.0} & 2.6 & 2.6 & 2.7 & 17.7 & 18.7 & 20.1 \\
\hline & \pm 0.03 & \pm 0.01 & \pm 0.01 & \pm 0.05 & \pm 0.04 & \pm 0.07 \\
\hline \multirow[t]{2}{*}{5.0} & 2.6 & 2.6 & 2.7 & 17.7 & 17.6 & 17.2 \\
\hline & \pm 0.03 & \pm 0.04 & \pm 0.03 & \pm 0.05 & \pm 0.07 & \pm 0.03 \\
\hline \multirow[t]{2}{*}{10.0} & 2.6 & 2.6 & 2.6 & 17.7 & 17.1 & 16.5 \\
\hline & \pm 0.03 & \pm 0.05 & \pm 0.05 & \pm 0.05 & \pm 0.06 & \pm 0.09 \\
\hline
\end{tabular}

$*$ Each value is the mean of ten replicates $\pm \mathrm{S}$. D. 
Int.J.Curr.Microbiol.App.Sci (2016) 5(4): xx-xx

Table.5 Effect of Toxicity of Cr (VI) on Changes in DNA and RNA (mg/g Fresh wt) in Pistia after different Durations of Contact*

\begin{tabular}{cccc}
\hline \multirow{2}{*}{$\begin{array}{c}\text { Root, shoot and Cr (VI) } \\
\text { With concentration }(\mathrm{ppm})\end{array}$} & \multicolumn{2}{c}{ Dry Weight (in mg/g Fresh wt) } \\
\cline { 2 - 4 } & 0 & 3 & Contact Time in Days \\
\hline Root & $80.1 \pm 0.001$ & $80.1 \pm 0.001$ & $80.1 \pm 0.001$ \\
control & $80.1 \pm 0.001$ & $80.5 \pm 0.005$ & $80.8 \pm 0.006$ \\
1.0 & $80.1 \pm 0.001$ & $83.2 \pm 0.004$ & $84.8 \pm 0.003$ \\
5.0 & $80.1 \pm 0.001$ & $88.2 \pm 0.006$ & $96.8 \pm 0.008$ \\
10.0 & $80.1 \pm 0.001$ & $90.6 \pm 0.005$ & $100.7 \pm 0.004$ \\
Shoot & $79.6 \pm 0.003$ & $79.6 \pm 0.003$ & $79.6 \pm 0.003$ \\
control & $79.6 \pm 0.003$ & $79.8 \pm 0.005$ & $79.9 \pm 0.003$ \\
1.0 & $79.6 \pm 0.003$ & $84.5 \pm 0.002$ & $86.2 \pm 0.001$ \\
5.0 & $79.6 \pm 0.003$ & $90.1 \pm 0.004$ & $97.4 \pm 0.005$ \\
10.0 & $79.6 \pm 0.003$ & $91.2 \pm 0.002$ & $100.5 \pm 0.001$ \\
& & & \\
\hline
\end{tabular}

* Each value is the mean of ten replicates $\pm \mathrm{S}$. D

Table.6 Effect of Toxicity of Cr (VI) on Changes in the Activities of Protease, Catalase, Peroxidase and Acid, Alkaline Pyrophosphatases in Pistia After 5 Days of Contact*

\begin{tabular}{|c|c|c|c|c|c|c|}
\hline \multirow[t]{2}{*}{$\begin{array}{l}\text { Root, shoot and Cr (VI) } \\
\text { With concentration (ppm) }\end{array}$} & \multirow{2}{*}{$\begin{array}{l}\text { Protease ( } \mu \mathrm{g} \\
\text { protein } / \mathrm{hr} / \mathrm{g} \\
\text { fresh wt) }\end{array}$} & \multirow{2}{*}{$\begin{array}{l}\text { Catalase } \\
\text { (enzyme } \\
\text { unit } / \mathrm{hr} / \mathrm{g} \\
\text { fresh wt) }\end{array}$} & \multirow{2}{*}{$\begin{array}{c}\text { Peroxidase } \\
\text { (enzyme } \\
\text { unit } / \mathrm{hr} / \mathrm{g} \\
\text { fresh wt) }\end{array}$} & \multicolumn{3}{|c|}{$\begin{array}{c}\text { Pyrophosphatase } \\
\text { (enzyme unit } / \text { unit } / \mathrm{hr} / \mathrm{g} \text { fresh wt) }\end{array}$} \\
\hline & & & & Acid & Alkaline & $\begin{array}{l}\text { Acid: } \\
\text { alkaline }\end{array}$ \\
\hline Root Initial activity & $275 \pm 1.5$ & $22 \pm 0.1$ & $18 \pm 0.09$ & $40 \pm 0.02$ & $88 \pm 0.04$ & $0.45 \pm 0.01$ \\
\hline Control & $341 \pm 1.58$ & $16 \pm 0.04$ & $22 \pm 0.08$ & $45 \pm 0.01$ & $86 \pm 0.21$ & $0.52 \pm 0.02$ \\
\hline 0.5 & $277 \pm 1.41$ & $14 \pm 0.09$ & $27 \pm 0.12$ & $43 \pm 0.01$ & $85 \pm 0.09$ & $0.51 \pm 0.03$ \\
\hline 1.0 & $251 \pm 1.55$ & $12 \pm 0.2$ & $29 \pm 0.15$ & $48 \pm 0.03$ & $84 \pm 0.08$ & $0.57 \pm 0.02$ \\
\hline 5.0 & $182 \pm 1.47$ & $6 \pm 0.01$ & $35 \pm 0.19$ & $60 \pm 0.08$ & $72 \pm 0.1$ & $0.88 \pm 0.01$ \\
\hline 10.0 & $127 \pm 0.9$ & $4 \pm 0.02$ & $46 \pm 0.16$ & $73 \pm 0.09$ & $61 \pm 0.09$ & $1.19 \pm 0.02$ \\
\hline Shoot Initial activity & $450 \pm 2.9$ & $20 \pm 0.2$ & $86 \pm 0.21$ & $357 \pm 0.27$ & $812 \pm 0.13$ & $0.44 \pm 0.03$ \\
\hline Control & $464 \pm 2.8$ & $17 \pm 0.04$ & $88 \pm 0.27$ & $398 \pm 0.35$ & $800 \pm 0.93$ & $0.50 \pm 0.04$ \\
\hline 0.5 & $448 \pm 1.9$ & $13 \pm 0.03$ & $87 \pm 0.09$ & $388 \pm 0.12$ & $796 \pm 0.35$ & $0.49 \pm 0.03$ \\
\hline 1.0 & $430 \pm 1.98$ & $11 \pm 0.01$ & $90 \pm 0.05$ & $395 \pm 0.15$ & $792 \pm 0.42$ & $0.50 \pm 0.01$ \\
\hline $\begin{array}{c}5.0 \\
10.0\end{array}$ & $\begin{array}{l}325 \pm 1.35 \\
132 \pm 1.2\end{array}$ & $\begin{array}{l}5 \pm 0.02 \\
3 \pm 0.005\end{array}$ & $\begin{array}{l}96 \pm 0.53 \\
99 \pm 0.41\end{array}$ & $\begin{array}{l}402 \pm 0.43 \\
452 \pm 0.41\end{array}$ & $\begin{array}{l}512 \pm 0.73 \\
301 \pm 0.17\end{array}$ & $\begin{array}{l}0.78 \pm 0.12 \\
1.50 \pm 0.16\end{array}$ \\
\hline
\end{tabular}

* Each value is the mean of ten replicates $\pm \mathrm{S}$. D. 
Toxic effect of $\mathrm{Cr}$ (VI) on the activities of protease, catalase, peroxidase and acid and alkaline pyrophosphatases after 5 days of contact is shown in Table VI. In all the treatments activities of protease, catalase and alkaline pyrophosphatase decreased in both root and shoot while an opposite trend in the activities of peroxidase and acid pyrophosphatase as well as the ratio of acid to alkaline pyrophosphatase activity were observed with increasing concentration of $\mathrm{Cr}$ (VI).

The increased activity of enzymes may be due to senescence of the plants and increased activity of a number of hydrolytic enzymes as suggested by Thomas and Stoddart (1980). A decrease in enzymatic activity may be due to formation of protein complex with $\mathrm{Cr}$ (III) changing the conformation and solubility of the protein.

Experiments conducted on the uptake of $\mathrm{Cr}$ (VI) by Pistia may enable one to understand the behavior of the metal toxicant discharge into the aquatic environment. From the foregoing results it is evident that at $10 \mathrm{ppm}$ concentration, $\mathrm{Cr}$ (VI) promotes senescence of Pistia plants by general inhibition of biosynthesis of cellular metabolites, impairing the degradation of the biochemical processes and also interfering with the nucleic acid biosysthesis and protein systhesizing machinery in the plant.

At concerntrations below 5 ppm $\mathrm{Cr}$ (VI), the metabolic activities of the plant are least affected, probably because there is a route by which the metal ion may be accumulated in the vacuolar system of the plant. It may be suggested that pistia plant can utilized as the scavenger of $\mathrm{Cr}$ (VI) from waste water.

\section{Acknowledgement}

The author are grateful to the Heads, Department of Botany and Chemistry, Visva- Bharati, Santiniketan for their help in providing laboratory facilities and constant encouragement. Financial support from the Ministry of Environment, Govt. of India in the form of research project and also to U.G.C New Delhi (India) are duly acknowledged.

\section{References}

Biswas, A.K. and Choudhuri, M.A. (1978). Differential behavior of the flag leaf of intact rice plant during ageing, Biochem. Physiol. Pflanzen., 173, 220228.

Black, C. C. and Mayne, B. C. (1970).P700 activity and chlorophyll concentration of plants with different photosynthetic carbon dioxide fixation cycles. Plant Physiol., 45, 738-741.

Burton, K. (1956). A study of the conditions and mechanism of the Diphenylamine Deoxyribonucleic acid. Biochem. J., 62, 325-323.

Chery, J. H. (1962). Nucleic acid determination in storage tissue of higher plants. Plant Physiol., 37, 670-678.

Choudhuri, M. A. and Chatterjee, S. K. (1970). Seasonal changes in the levels of some cellular components in the abscission zone of Coleus leaves of different ages. Ann. Bot., 34, 275-287.

De, A. K., Sen, A. K., Modak, D. P. and Jana, S. (1985). Studies of toxic effects of $\mathrm{Hg}$ (II) on Pistia Stratiotes. Water, Air and Soil Pollution., 24, 351360.

Dwivedi, S., Kar, M. and Mishra, D. (1979). Biochemical changes in excised leaves of Oryza stiva subjected to water stress. Physiol. Plant., 45, 35-40.

Fick, N. G. and qualsett, C. O. (1975). Genetic control of endosperm amylase 
activity and gibberellins responses in standard height and short-statured wheat. Proc. Natl. Acad. Sci., USA, 72, 892895.

Hewitt, E. J. (1963). Plant Physiology, Vol. 3, F. C. Steward (ed.), Acadimic Press, New York, pp. 1-97.

Jana, S. and Choudhuri, M. A. (1982). Senescence in submerged aquatic angiosperms : effects of heavy metals. New phytol., 90, 477-484.

Kaniuga, Z., Sochanowicz, B., Zabek, J. and Krzystyniak, K. (1978). Photosynthetic apparatus in Chilling- sensitive plants. I. Reactivation of Hill reaction activity inhibited on the cold and dark storge of detached leaves and intact plants. Plants., 140, 121-128.

Kar, M. and Mishra, D. (1975). Inorganic pyrophosphatase acivity during rice leaf senescence. Can. J. Bot., 53, 503-510.

Kar, M. and Mishra, D. (1976). Catalase, peroxidase, polyphenol oxidase activities during rice leaf nsenescence. Plant Physiol., 57, 315-319.

Knudson, L. L., Pibbilts, T. W. and Edwards, G. E. (1977). Measurement of ozone injury by determination of leaf chlorophyll concentration. Plant Physiol., 60, 606-608.

Lowry, O. H., Rosebrough, N. J., Far, A. L. and Randall, R. J. (1951). Protein measurement with Folin-Phenol reagent. J. Biol. Chem., 193, 265-275.

Markham, R. (1955). Nucleic acids, their components and related compounds. In : Modern methods of Plant Analysis (Ed. By K. Paech and M. V. Tracey), Vol. IV,
Springer-Gerlag, Berlin, ppo. 246-304.

Moore, S. and Stein, W. W. (1948).Photometric ninhydrin method for use in the chromatography of amino acids. J. Biol. Chem., 176, 367-388.

Sandell, E. B. (1965). Procedures for the determination of traces of metals. In : Colorimetric Determination of Traces of Metals. Interscience publishers, Inc., New York, ppo. 388-408.

Sen, A. K. and Ghatuary, R. K. (1979) Note on the selective separation of chromium from ferrochrome alloy. Fresnius $\mathrm{Z}$. Anal. Chem., 295, 414-415.

Sen, A. K. and Ghosh, U. C. (1980). A rapid method for selective separation and estimation fof chromium ikn some ores and alloys by hydrated zirconium dioxixde ionexchanger. J. Indian Chem. Soc., 57, 103-105.

Shioi, Y., Tamai, K. and Sasa, T. (1978). Inhibition of photosystem II in the green algae Ankistro-desmus falcatus by copper. Physiol. Plant., 44, 434-438.

Sigel, H. (1973). Metal ion in Biological systems, Vol. 2, Marcel Dekker Inc., New York.

Snell, F. D. and Snell, C. T. (1971). Colorimetric methods of analysis, Vol. IV, Van Nostrand Reinhold Co, New York, pp. 7-145.

Sterrett, F. (1978). Ddinking water standards. Scavenger, 8, 7-19.

Thomas, H. and Stoddart, J. L. (1980). Leaf Senescence. Ann. Rev. Plant Physiol., 31, 83-111.

\section{How to cite this article:}

Piyush Kanti Dan, Sunandana Mandal, Anil Kr. De and Sudhendu Mandal. 2016. Studies on the Toxicity of Chromium (VI) to Pistia stratiotes L. Plant and its Removal. Int.J.Curr.Microbiol.App.Sci.5(5): 975-982. doi: http://dx.doi.org/10.20546/ijcmas.2016.505.103 